This document was prepared in conjunction with work accomplished under Contract No. DE-AC09-08SR22470 with the U.S. Department of Energy.

This work was prepared under an agreement with and funded by the U.S. Government. Neither the U. S. Government or its employees, nor any of its contractors, subcontractors or their employees, makes any express or implied: 1. warranty or assumes any legal liability for the accuracy, completeness, or for the use or results of such use of any information, product, or process disclosed; or 2. representation that such use or results of such use would not infringe privately owned rights; or 3 . endorsement or recommendation of any specifically identified commercial product, process, or service. Any views and opinions of authors expressed in this work do not necessarily state or reflect those of the United States Government, or its contractors, or subcontractors. 


\section{United States Department Of Energy Office of Environmental Management International Program Annual Report for 2007}

S. L. Krahn, K. D. Gerdes, J. C. Marra*, D. K. Peeler*, J. R. Harbour*, K. M. Fox*, J. D. Vienna**, A. S. Aloy $^{+}$, S. V. Stefanovsky ${ }^{++}$and M. D. Bondarkov ${ }^{+++}$

Office of Engineering and Technology

Office of Environmental Management

U.S. Department of Energy, EM-20/Germantown, 1000 Independence Ave., S.W., Washington, DC 20585-1290

*Savannah River National Laboratory, Savannah River Site, P.O. Box 616, Aiken, SC 29808

**Pacific Northwest National Laboratory, P. O. Box 999, Richland, WA, 99352

${ }^{+}$Khlopin Radium Institute, St. Petersburg, Russia

${ }^{++}$SIA Radon, Moscow, Russia

${ }^{+++}$International Radioecology Laboratory, Slavutych, Ukraine 


\section{TABLE OF CONTENTS}

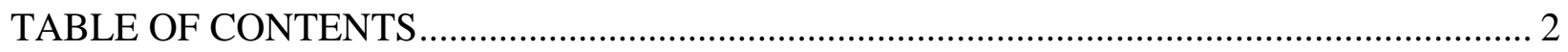

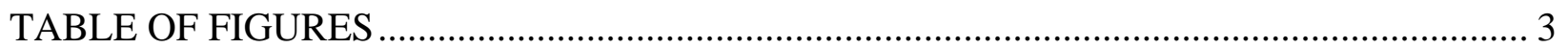

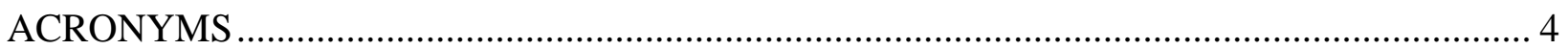

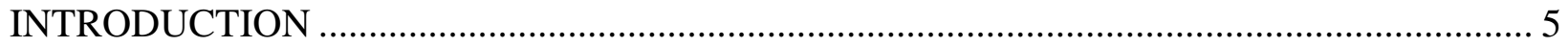

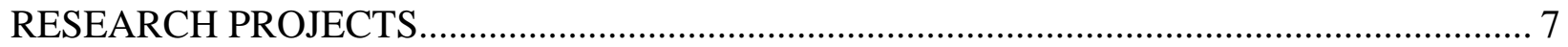

Application of the Cold Crucible Induction Heated Melter to DOE Wastes................................ 7

Improved Solubility and Retention of Troublesome Components in SRS and Hanford HLW

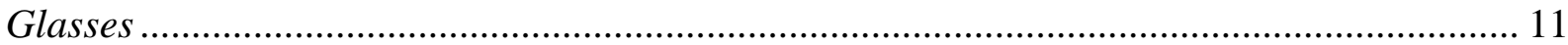

Long-term Impacts from Radiation/Contamination within the Chernobyl Exclusion Zone ..... 16

Cold Crucible Induction Melter Demonstration With SRS Slurry Feed Simulant..................... 19

FUTURE INITIATIVES FOR INTERNATIONAL PROGRAM ................................................. 20

PAPERS/PRESENTATIONS RESULTING FROM PROJECTS ……......................................... 21

RECOGNITIONS RESULTING FROM DOE-EM INTERNATIONAL PROGRAM................. 22

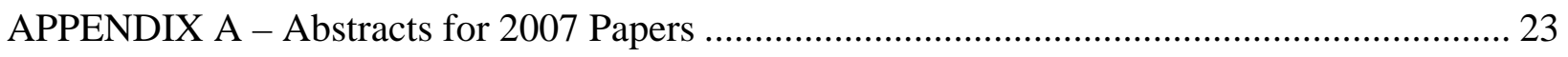

Towards a Global Nuclear Renaissance: A New Paradigm for Waste Management ............... 23 Characterization of the Glass-Ceramic Material Prepared Upon Vitrification of an Ironcontaining Surrogate of High-level Wastes in a Cold Crucible ............................................... 23 Glass Formulation Development in Support of Melter Testing to Demonstrate Enhanced High Level Waste Throughput ..................................................................................................... 24

Cold Crucible Vitrification of Uranium-Bearing High Level Waste Surrogate ........................ 24

Vitrification of Simulated Iron-Aluminum High-Level Radwaste: Experimental Results ........ 25

Vitrification of Savannah River Site SB4 Waste Surrogate in the Radon Bench-Scale Cold Crucible Unit ............................................................................................................... 25

Current Progress and Future Plans for the DOE Office of Environmental Management International Program ................................................................................................... 26

Improved Alumina Loading in High-Level Waste Glasses .................................................... 27 Cold Crucible Vitrification of Savannah River Site SB4 Waste Surrogate: Process Variables and Product Characterization .............................................................................................. 27 Vitrification of Waste Surrogate of Savannah River Plant (USA) with High Iron and Aluminum Content at the Bench- and Industrial-Scale Plants with Cold Crucible ................................... 28 Valence State and Speciation of Uranium Ions in Borosilicate Glasses with High Iron and

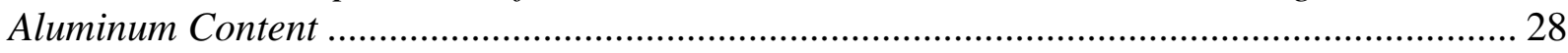

\section{E Environmental Management}




\section{TABLE OF FIGURES}

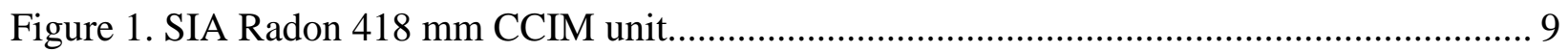

Figure 2. Operating industrial scale CCIM at Sergiev Posad facility.......................................... 10

Figure 3. Original image. White inclusions are spinel.............................................................. 12

Figure 4. Digitized image. Red dots are spinel..................................................................... 12

Figure 5. Processed image with each spinel particle recorded and numbered.............................. 12

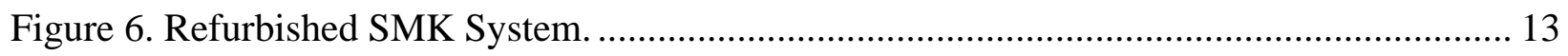

Figure 7. Schematic of the EP-5 System. …………............................................................. 14

Figure 8. Glass pour from the EP-5 System. ................................................................... 14

Figure 9. Environmental monitoring in the Chernobyl Exclusion Zone. ...................................... 17

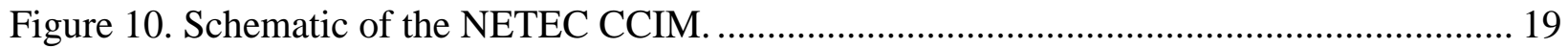

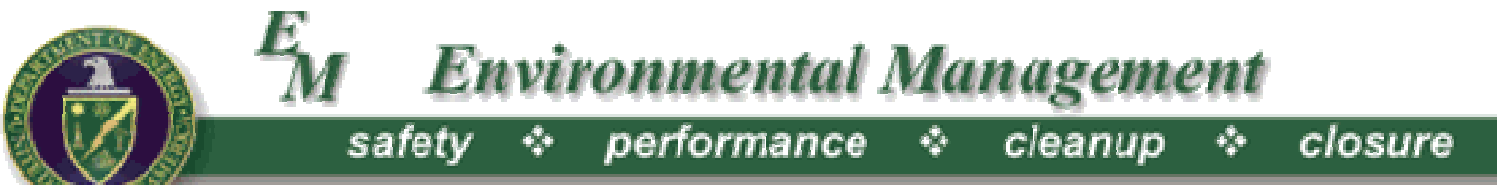




\section{ACRONYMS}

CCC

CCIM

ChEZ

ChNPP

D\&D

DOE

DWPF

EA

EM

GNEP

HLW

ICEM

IRL

JHM

KRI

LAW

LWO

NDA

NETEC

PCT

PNNL

SB

SRNL

SRS

WM

XRD
Canister Centerline Cooling

Cold Crucible Induction Melter

Chernobyl Exclusion Zone

Chernobyl nuclear power plant

Deactivation and Decommissioning

Department of Energy

Defense Waste Processing Facility

Environmental Assessment

Environmental Management

Global Nuclear Energy Partnership

high-level waste

International Conference on Environmental

Remediation and Radioactive Waste

Management

International Radioecology Laboratory

Joule Heated Melter

Khlopin Radium Institute

low-activity waste

Liquid Waste Organization

Nuclear Decommissioning Authority

Nuclear Engineering and Technology Institute

Product Consistency Test

Pacific Northwest National Laboratory

Sludge Batch

Savannah River National Laboratory

Savannah River Site

Waste Management

$\mathrm{X}$-ray diffraction 


\section{INTRODUCTION}

The DOE-EM Office of Engineering and Technology is responsible for implementing EM's international cooperative program. The Office of Engineering and Technology's international efforts are aimed at supporting EM's mission of risk reduction and accelerated cleanup of the environmental legacy of the nation's nuclear weapons program and government-sponsored nuclear energy research. To do this, EM pursues collaborations with government organizations, educational institutions, and private industry to identify and develop technologies that can address the site cleanup needs of DOE.

The Office of Engineering and Technology has developed a Technology Roadmap ${ }^{1}$ and a Multi-year Program Plan to identify technology needs and identify areas for focused research and development to support DOE-EM's environmental cleanup and waste management objectives. The international cooperative program is an important element of the technology development roadmap, leveraging of world-wide expertise in the advancement and deployment of remediation and treatment technologies. Introductory briefings aimed at furthering familiarity with the DOE-EM mission, and the vital role that technology development plays within it, were presented at two international meetings.

The Office of Engineering and Technology currently works with the Khlopin Radium Institute (KRI) and SIA Radon Institute in Russia, the International Radioecology Laboratory (IRL) in Ukraine and the Nuclear Engineering and Technology Institute (NETEC) in South Korea through cooperative bilateral arrangements to support EM's accelerated cleanup and closure mission. ${ }^{2}$ Specific 2007 initiatives included:

- Application of the Cold Crucible Induction Heated Melter to DOE Wastes - SIA Radon and Savannah River National Laboratory;

- Improved Solubility and Retention of Troublesome Components in SRS and Hanford Waste Glasses - Khlopin Radium Institute, Pacific Northwest National Laboratory and Savannah River National Laboratory

- Long-term Impacts from Radiation/Contamination within the Chernobyl Exclusion Zone, International Radioecology Laboratory and Savannah River National Laboratory.

- Cold Crucible Induction Melter Demonstration with SRS Slurry Feed Simulant, Nuclear Engineering and Technology Institute and Savannah river National Laboratory

- Participation in International Conferences in Belgium, South Korea, England and Russia

o "International Conference on Environmental Remediation and Radioactive Waste Management (ICEM),” Bruges, Belgium

o "International Symposium on Radiation Safety Management,” Daejeon, South Korea

o "Materials Research Society Scientific Basis for Nuclear Waste Management," Sheffield, England

o “AtomEco 2007,” Moscow, Russia

\footnotetext{
1 “Engineering and Technology Roadmap - Reducing Technical Risk and Uncertainty in the EM Program,” U.S. Department of Energy - Office of Environmental Management (DOE-EM), March 2008.

${ }^{2}$ K.D. Gerdes, J. R. Harbour, J. C. Marra, D. K. Peeler, J. A. Roach, J. D. Vienna, T. B. Calloway, A. S. Aloy, S. V. Stefanovsky and M. D. Bondarkov, "The U.S. Department of Energy - Office of Environmental Management's International Program,” WM’07, Tucson AZ, February 25 - March 1, 2007.
}

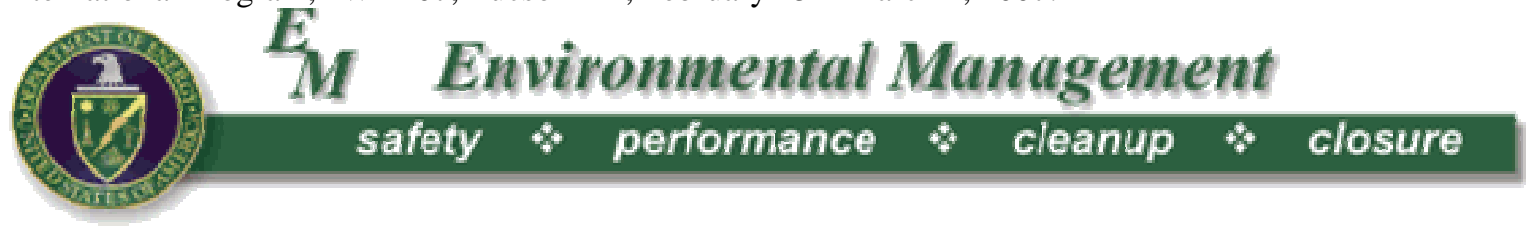


The 2007 International Program activities were highly successful providing valuable data and information to support DOE-EM cleanup activities. The 2007 efforts resulted in 13 external publications and presentations and several recognitions for International Program project partners.

The latest results from the current bilateral collaboration projects being implemented by EM in support of the EM accelerated cleanup and closure mission are included in this report. Discussion regarding efforts to integrate the international cooperative program with the current engineering and technology development program is also included. 


\title{
RESEARCH PROJECTS
}

\section{Application of the Cold Crucible Induction Heated Melter to DOE Wastes}

\author{
Principal Investigator(s): S.V. Stefanovsky (SIA Radon), J.C. Marra (SRNL) \\ Collaborator(s): A.P. Kobelev, V.V. Lebedev, M.A. Polkanov, A.G. Ptashkin, O.A. Knyazev
}

\section{Research Objectives}

This effort continued the evaluation of the Cold Crucible Induction Melter (CCIM) technology as a means to increase waste loading and waste throughput for the Savannah River Site's Defense Waste Processing Facility (DWPF). Specific attention in 2007 was given to processing of high alumina content feeds. The DWPF Sludge Batch 4 (SB4) surrogate composition, representing the highest alumina content feed processed to date in the DWPF, was selected for testing. Compositions with high alumina concentrations have the potential to increase nepheline $\left(\mathrm{NaAlSiO}_{4}\right)$ crystal formation in the glass. ${ }^{3}$ The formation of nepheline can have a detrimental impact on glass durability because it decreases the amount of the glass forming oxides $\mathrm{Al}_{2} \mathrm{O}_{3}$ and $\mathrm{SiO}_{2}$ in the residual glass matrix. Additionally, the refractory nature of alumina may have a negative impact on melting rate for high alumina concentration feeds. $^{4}$

The reference Joule Heated Melter (JHM) technology has a process temperature of $1150^{\circ}$ C. This temperature limitation combined with

${ }^{3}$ D.K. Peeler, T.B. Edwards, D.R. Best, I.A. Reamer and R.J. Workman, "Nepheline Formation Study for Sludge Batch 4 (SB4): Phase 2 Experimental Results,” WSRC-TR-2006-00006, Washington Savannah River Company, Aiken, SC (2006)

${ }^{4}$ M. E. Smith and D. H. Miller, "Initial SB4 Melt

Rate Furnace Testing,” WSRC-TR-2005-00339, Washington Savannah River Company, Aiken, SC (2005).

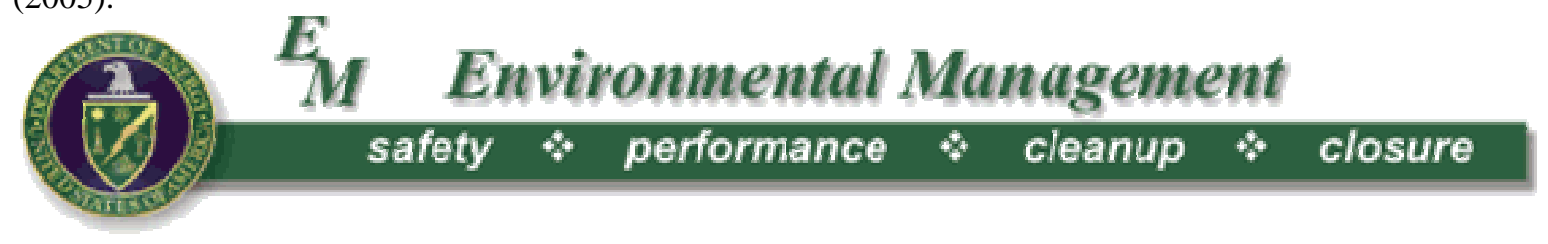

the refractory nature of the high alumina feeds has the potential to hamper continued waste throughput improvements with the current JHM technology. The CCIM technology offers the potential for higher vitrification process temperatures which could lead to increased waste loading and melting rates for high alumina concentration feeds.

\section{Research Progress}

The 2007 test program focused on demonstrating high waste loading of the SB4 feed without detrimentally impacting glass properties or melter processing. To accomplish this objective, a two-phased testing approach was used: i) glass composition development to identify a frit composition to increase waste loading and maintain acceptable glass properties and ii) demonstrating CCIM processing in a series of varying scale melter tests.

A previously developed frit composition (Frit 503) was used by SRNL researchers as a starting point for frit composition development. Frit 503 was modified by lowering the sodium content and/or increasing the boron content. It was hypothesized that removing sodium from the glass would reduce the tendency for nepheline formation and the negative impacts on durability. Additionally, the decrease in alkali content would result in an increase in $\mathrm{SiO}_{2}$ concentration, further reducing the tendency for nepheline formation. Increasing boron content was also postulated as a means to reduce the 
tendency for nepheline formation. ${ }^{5}$ The compositional adjustments were also made with the processing conditions and requirements of the CCIM in mind. The identified candidate frit compositions are shown in Table I. Glasses were fabricated using all five candidate frit compositions with SB4 waste loadings of 40, 45, 50 , and $55 \mathrm{wt} \%$, each. The compositions were batched using oxide chemicals and melted at $1250^{\circ} \mathrm{C}$ in $\mathrm{Pt} / \mathrm{Rh}$ crucibles. After nominally two hours at temperature, the glasses were quenched by pouring on a steel plate. A portion of the glass was heat treated to simulate cooling along the centerline of the DWPF canister (i.e. Canister Centerline Cooling (CCC) profile). ${ }^{6}$ Both quenched and CCC glass samples were then evaluated for crystallization using X-ray diffraction (XRD) and response to the Product Consistency Test Method A Procedure (PCTA). ${ }^{7}$

Table 1. Candidate frit formulations for CCIM testing (oxide concentrations in wt \%).

\begin{tabular}{|c|c|c|c|c|c|}
\hline Frit ID & $\mathbf{B}_{\mathbf{2}} \mathbf{O}_{3}$ & $\mathbf{L i}_{\mathbf{2}} \mathbf{O}$ & $\mathbf{N a}_{\mathbf{2}} \mathbf{O}$ & $\mathbf{S i O}_{\mathbf{2}}$ & Total \\
\hline 503-R1 & 14.0 & 8.0 & 2.0 & 76.0 & 100.0 \\
\hline 503-R2 & 14.0 & 8.0 & -- & 78.0 & 100.0 \\
\hline 503-R3 & 16.0 & 8.0 & 2.0 & 74.0 & 100.0 \\
\hline 503-R4 & 16.0 & 8.0 & -- & 76.0 & 100.0 \\
\hline 503-R5 & 18.0 & 8.0 & -- & 74.0 & 100.0 \\
\hline
\end{tabular}

Based on the results of the experimental testing composition 503-R4 was selected for follow-on CCIM testing with the SB4 composition. This composition exhibited more than adequate durability as determined by the PCT and, unlike the other frit formulations, no evidence of

${ }^{5}$ H. Li, P. Hrma, J.D. Vienna, M. Qian, Y. Su and D.E. Smith, "Effects of $\mathrm{Al}_{2} \mathrm{O}_{3}, \mathrm{~B}_{2} \mathrm{O}_{3}, \mathrm{Na}_{2} \mathrm{O}$, and $\mathrm{SiO}_{2}$ on Nepheline Formation in Borosilicate Glasses: Chemical and Physical Correlations, J. NonCrystalline Solids, 331 (2003).

${ }^{6}$ S. L. Marra and C. M. Jantzen, "Characterization of Projected DWPF Glass Heat Treated to Simulate Canister Centerline Cooling,” WSRC-TR-92-142, Revision 1, Westinghouse Savannah River Company, Aiken, SC (1993).

7 "Standard Test Methods for Determining Chemical Durability of Nuclear Waste Glasses: The Product Consistency Test (PCT),” ASTM C-1285, (2002). nepheline formation was found in $55 \mathrm{wt} \%$ waste loading glasses even after CCC heat treatment. However, it should be noted that the lack of nepheline in the 503-R4 glass may have been a result of sampling or an analytical detection limit issue for this glass.

A series of melter test campaigns was completed at the SIA Radon test facilities utilizing the Frit 503-R4 compositions with various levels of SB4 waste loading. Initial testing was conducted in a lab-scale $56 \mathrm{~mm}$ diameter CCIM unit. This test included the addition of uranium oxide in the waste surrogate to evaluate the partitioning of uranium within the vitrified product. Testing was conducted at 40 and 50\% waste loading (on a calcined oxide wt $\%$ basis). The resulting glass products consisted of primarily an amorphous matrix with some spinel crystals (enriched in transition metal ions) present. Uranium was only found in the glassy matrix and, therefore, did not partition to the crystalline phase. This initial testing provided confidence in the ability of the CCIM to process the SB4 waste composition and led to larger-scale testing.

The second test campaign was performed in the pilot-scale, $216 \mathrm{~mm}$ diameter, CCIM located at the SIA Radon Sergiev Posad facility. The first test processed the SB4 composition at $40 \mathrm{wt} \%$ waste loading while the second test started with a $40 \mathrm{wt} \%$ waste loading glass and progressed to a $60 \mathrm{wt} \%$ waste loading feed. The latter test allowed a progressive evaluation of processing from 40-60 wt \% waste loading. All these tests used the simulated SB4 waste slurry and the Frit 503-R4 composition that was simulated using oxide chemicals. The testing provided insight into melter operations (e.g. power levels, production rate, etc.) and again provided confidence to move to the next scale of testing. The glass products produced from the testing were primarily vitreous with a minor spinel phase present. The concentration of the spinel phase was a maximum ( 10 vol \%) in the $60 \mathrm{wt}$ $\%$ waste loading glass.

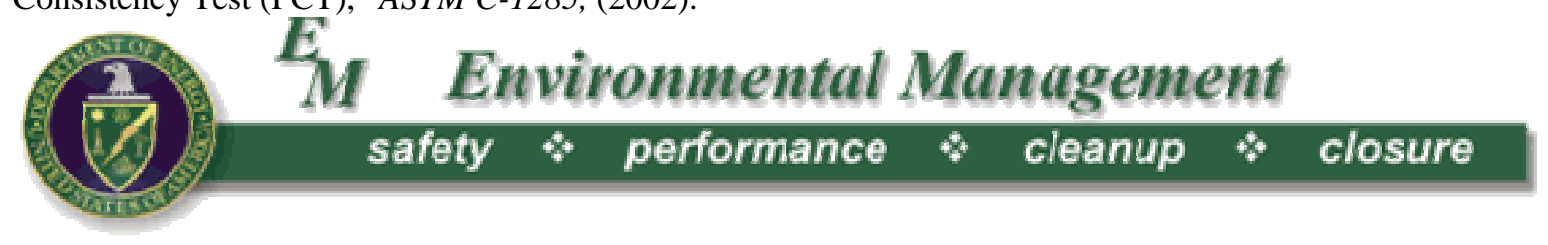


The final test campaign was conducted in the production-scale, $418 \mathrm{~mm}$ diameter, CCIM. This unit is located at the SIA Radon Sergiev Posad facility and is shown schematically in Figure 1. A $50 \mathrm{wt} \%$ SB4 waste loading target was selected for the testing. The waste composition was spiked with $\mathrm{CsNO}_{3}$ to evaluate Cs volatility. Frit 503-R4 was fabricated in the U.S. and shipped to Russia to support the testing. The frit was sized to be consistent with current DWPF frit specifications. The test was conducted for 66 hours and approximately 460 $\mathrm{kg}$ of glass was produced with an average specific glass production rate of about 100 $\mathrm{kg} /\left(\mathrm{m}^{2}-\mathrm{hr}\right)$. Melter operation and off-gas data were obtained from the testing. Photos of the operating melter are shown in Figure 2. The resulting glass product was primarily vitreous with about $12 \mathrm{vol} \%$ spinel phase dispersed in the glass matrix. The crystalline content was higher in this testing vs. $216 \mathrm{~mm}$ CCIM testing due to the slow cooling of the glass receipt containers in the annealing furnace in the production-scale system. The durability of the $50 \mathrm{wt} \%$ SB4 glass, as determined by B release from the glass in the PCT-A, was an order of magnitude better than the Environmental Assessment (EA) glass. The EA glass is the current benchmark glass used for repository qualification in the U.S. ${ }^{8}$ Cesium volatility from the glass was estimated to be greater than $50 \mathrm{wt}$ $\%$. Future testing will be conducted to better quantify this volatility and to evaluate means to reduce volatility.

\section{Significant 2007 Accomplishments:}

- Glass formulation efforts led to a frit formulation that allowed for high waste loadings of a high alumina content waste that was suitable for processing in the CCIM.

${ }^{8}$ C. M. Jantzen, N. E. Bibler, D. C. Beam, C. L. Crawford and M. A. Pickett, "Characterization of the Defense Waste Processing Facility (DWPF) Environmental Assessment (EA) Glass Standard Reference Material,” U.S. Department of Energy Report WSRC-TR-92-346, Revision 1, Westinghouse Savannah River Company, Aiken, SC, 1993.
- The ability to vitrify an SRS defense waste SB4 surrogate at high waste loading in the CCIM was demonstrated via testing at several scales. An extended test campaign at $50 \mathrm{wt} \%$ SB4 waste loading was successfully completed in the SIA Radon $418 \mathrm{~mm}$ diameter production-scale CCIM with an average specific glass production rate of about $100 \mathrm{~kg} /\left(\mathrm{m}^{2}-\mathrm{hr}\right)$. The resulting glass product was of excellent quality.

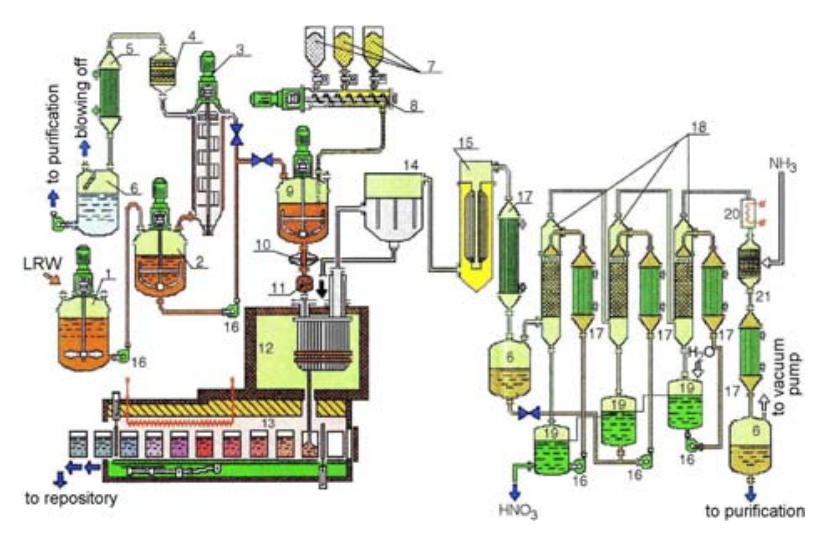

Figure 1. SIA Radon 418 mm CCIM unit.

1 - Interim storage tank, 2 - Concentrate collector, 3 - Rotary film evaporator, 4 \& 15 - HEPA-filters, 5, 17 \& 21 - Heat-exchangers, 6 \&19 - Reservoirs, 7 Glass forming additives hoppers, 8 - Screw feeder, 9 - Batch mixer, 10 - Mechanical activator, 11 Peristaltic pump, 12 - Cold crucible, 13 - Annealing furnace, 14 - Sleeve (coarse) filter, 16 - Pumps, 18 Absorption columns, 20 - Heater.

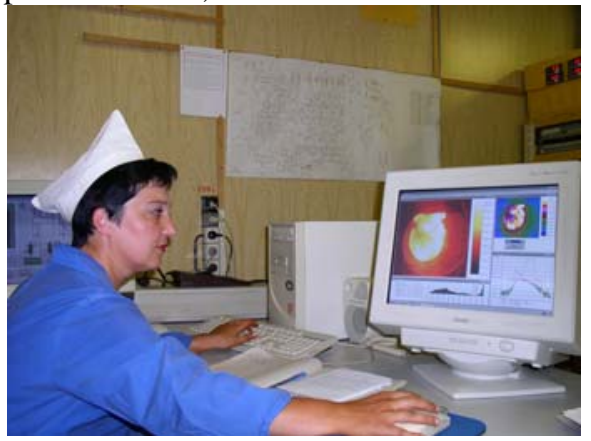

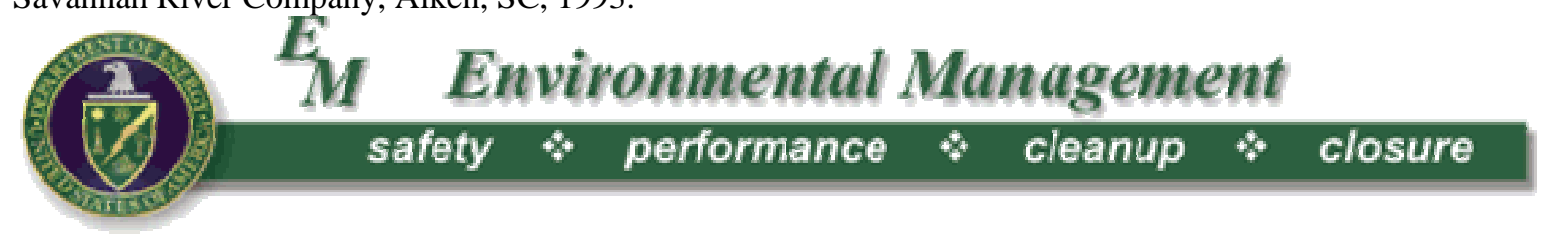




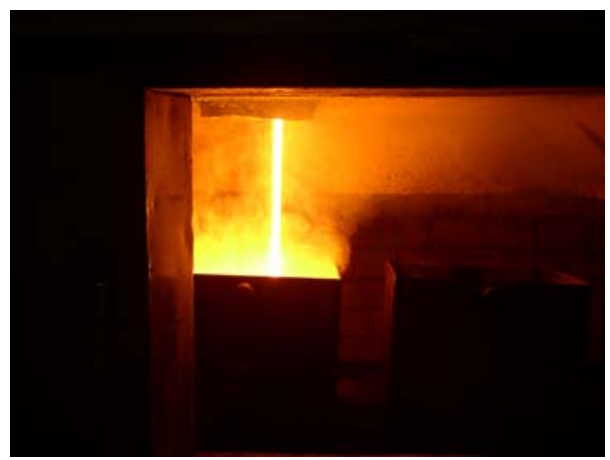

Figure 2. Operating industrial scale CCIM at Sergiev Posad facility.

Top - control and data acquisition system; Bottom glass pour.

\section{Planned Activities}

Future testing is planned to evaluate processing of other troublesome high level waste feeds. Continued evaluation of volatility from the melt (especially cesium) is also planned. In addition to quantifying volatility, means to reduce volatility from the melt will be investigated. Crystallization within the melt pool will be evaluated with an emphasis on determining impacts on long term operation. 


\section{Improved Solubility and Retention of Troublesome Components in SRS and}

\section{Hanford HLW Glasses}

Principal Investigator(s): A.S. Aloy (Khlopin Radium Institute), D.S. Kim (PNNL), K.M. Fox (SRNL) Collaborator(s): A. Trofimenko, R. Soshnikov, V. Belov, E. Kovarskaya, O. Iskhakova, S. Samoylov, A. Khoroshaylov (Khlopin Radium Institute), J.D. Vienna (PNNL), D.K. Peeler (SRNL)

\section{Research Objectives}

The U.S. DOE is currently processing high-level waste (HLW) through a JHM at the Savannah River Site (SRS) and plans to process HLW through a JHM at the Hanford Site. The process combines the HLW sludge with a prefritted additive (DWPF at SRS) or with mined mineral glass forming additives (Hanford). The combination is subsequently melted, and the molten glass is poured into stainless steel canisters to create the final waste form. In preparation for the qualification and receipt of each sludge batch, development and definition of various tank blending and/or washing strategies are often evaluated. The various strategies are contemplated in an effort to meet critical site objectives or constraints such as those associated with tank volume space, transfer options, and settling issues. Although these objectives or constraints are critical, one must not lose sight of both process and product performance issues associated with the final waste form. The product performance issue relates to the durability of the glass waste form (both fast and slow cooled). Process related issues (e.g., liquidus temperature, viscosity, electrical conductivity, and melting rate considerations) ultimately dictate the efficiency and effectiveness of the melter operation. The composition and loading of waste in the glass impact all of these issues.

Tank retrieval and blending strategies at both SRS and Hanford have identified high $\mathrm{Al}_{2} \mathrm{O}_{3}$ waste streams that are scheduled to be processed through their respective HLW vitrification facilities. These streams have $\mathrm{Al}_{2} \mathrm{O}_{3}$ concentrations above 25 wt \% (on a calcined oxide basis). For example, the Liquid Waste Organization (LWO) at SRS has provided compositional projections for the next sludge batch (Sludge Batch 5) to be processed in the DWPF with $\mathrm{Al}_{2} \mathrm{O}_{3}$ concentrations up to $31 \mathrm{wt} \%$ (assuming aluminum dissolution is not implemented). In addition, physical limitations in the Tank Farms and/or settling issues associated with the sludge have prevented "advanced" washing which has resulted in relatively high $\mathrm{Na}_{2} \mathrm{O}$ (23 to 27 wt \%) and $\mathrm{SO}_{3}$ ( $0.8-1.6$ wt \%) concentrations. Current Hanford projections suggest the $\mathrm{Al}_{2} \mathrm{O}_{3}$ concentrations in sludge could be much greater than those currently projected for DWPF, with $\mathrm{Al}_{2} \mathrm{O}_{3}$ concentrations as high as $80 \mathrm{wt} \%$.

Under this task, researchers from the Pacific Northwest National Laboratory (PNNL), Savannah River National Laboratory (SRNL), and Khlopin Radium Institute (KRI) are collaborating to conduct experiments that will develop glass formulations for specific DOE waste streams with high $\mathrm{Al}_{2} \mathrm{O}_{3}$ concentrations. The glasses should meet or exceed waste loading and/or waste throughput expectations as well as satisfying critical process and product performance related constraints. Secondary objectives of this task are to assess the melting rate for various glass frits for the DWPF composition and spinel settling for the Hanford composition.

\section{Research Progress}

The International Team developed and fabricated an integrated test matrix of 70 glasses

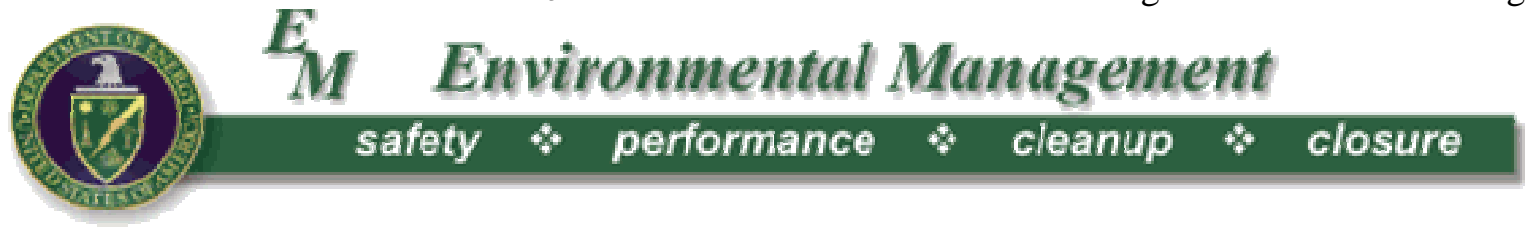


that have provided valuable compositional property relationship data from which optimization studies can be based. The 70 glasses were statistically designed to cover glass composition regions of interest to both DWPF and Hanford. The team has completed characterization of specific properties of interest including durability, liquidus temperature, homogeneity and viscosity. Particular attention has been paid to crystallization within the glasses. An example of the identification and quantification of spinels in one of the test matrix glasses is shown in Figures 3 through 5. Further evaluation of these data is underway, and will be used to support development of glass composition - property models for high $\mathrm{Al}_{2} \mathrm{O}_{3}$ concentration glass systems.

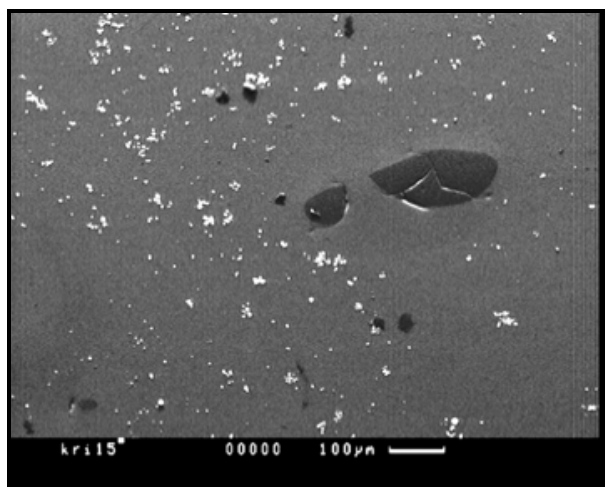

Figure 3. Original image. White inclusions are spinel.

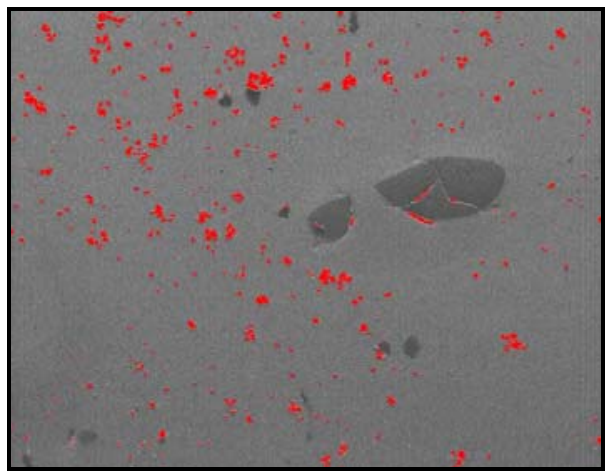

Figure 4. Digitized image. Red dots are spinel.

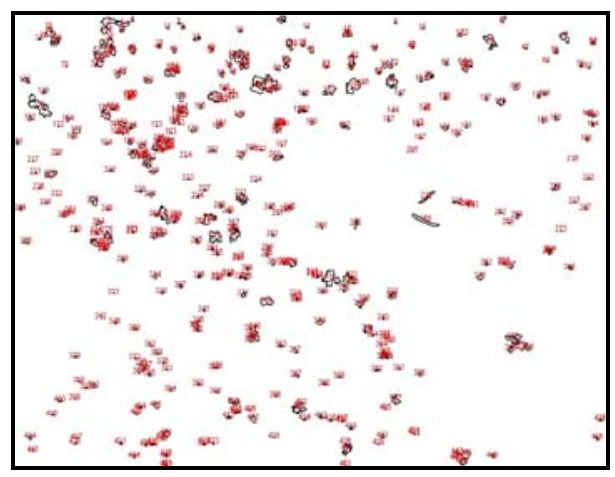

Figure 5. Processed image with each spinel particle recorded and numbered.

Results from the glass test matrix were also used by the team to select glass compositions of interest for melter testing. For Hanford, a waste composition high in alumina was selected in consultation with DOE with a nominal $53 \mathrm{wt} \%$ $\mathrm{Al}_{2} \mathrm{O}_{3}$ content and a glass system containing approximately $26 \mathrm{wt} \% \mathrm{Al}_{2} \mathrm{O}_{3}$ (HAL-17) was formulated. The goal of the Hanford test was to evaluate melt crystallization under various process conditions. SRNL selected Sludge Batch 5 (SB5) as the basis for its share of the melter testing, as this will be the next waste stream to be processed in the DWPF. With this composition, testing will be conducted on an SB5 composition with low $\mathrm{Al}_{2} \mathrm{O}_{3}$ and high $\mathrm{Al}_{2} \mathrm{O}_{3}$ concentrations to represent both flowsheet options (i.e. flowsheets with and without $\mathrm{Al}_{2} \mathrm{O}_{3}$ dissolution). Therefore, the primary objective of this test will be to evaluate the potential melt rate differences between the high and low $\mathrm{Al}_{2} \mathrm{O}_{3}$ based sludges as well as gain insight into the impact of frit composition on the melt rate of both sludge types. To support the testing, KRI refurbished two test melters as described below.

\section{The SMK System}

The SMK system is a small-scale melter system located at the Khlopin Radium Institute that can be used to evaluate crystallization within the melter and in the poured glass. The melter can also be used to study various frit compositions to evaluate melting behavior and determine relative melting rate prior to pilot-scale testing.

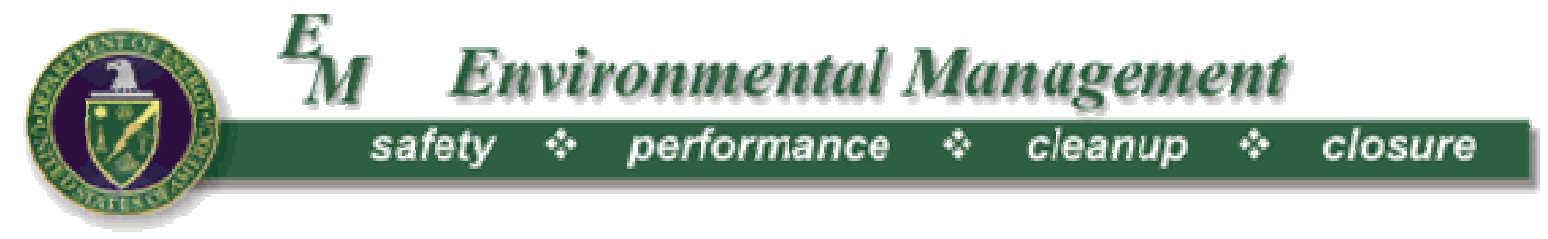


The SMK is a stainless steel can (alloy EI-0652) with the internal volume of about $1200 \mathrm{~cm}^{3}$. A pour spout made of the same alloy is welded into the melter bottom. A pour closure pipe is installed vertically inside the assembly on the centerline to open/close the pore spout. An arm installed on the melter lid lifts and lowers the pour closure pipe. The melter crucible is heated by eight resistively heated silicon carbide elements. Photos of the SMK system are provided in Figure 6.

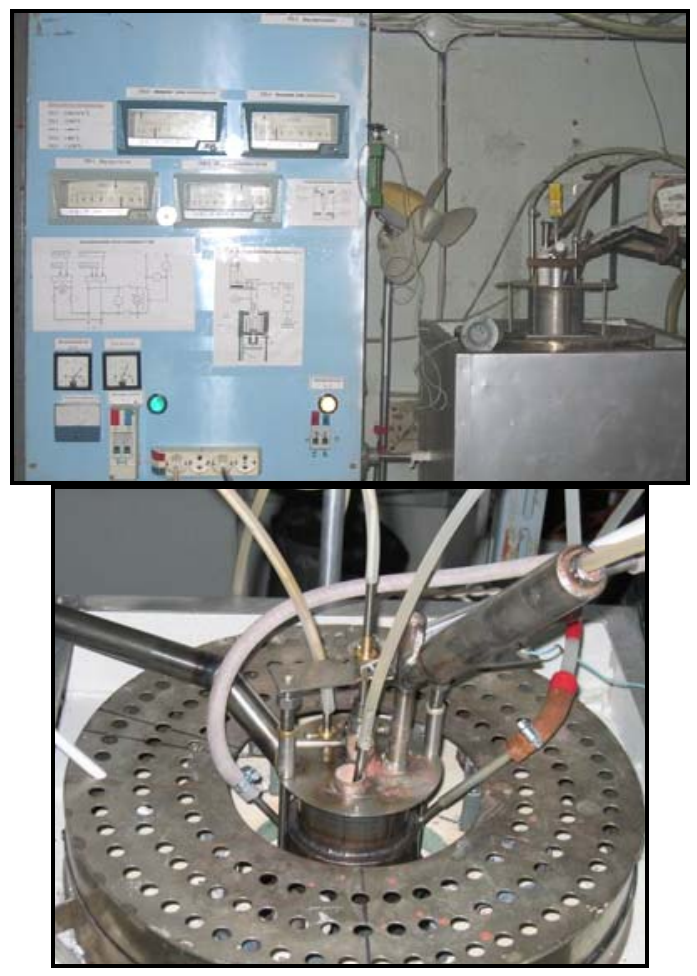

Figure 6. Refurbished SMK System.

Top - Overview of melter system; Bottom - Top head components.

The slurry is fed to the SMK melter from a feeder tank through the water-cooled tube using a peristaltic pump. The slurry is stirred continuously in the feeder tank. The final glass product is poured into removable, insulated steel collector cans placed on the scales with a lifting mechanism. When the collector can is lifted into the upper position, the melt area is sealed preventing cold air from contacting the pour spout in the lower ceramic plate. When the collector can is in the lowest position, it becomes readily accessible.

Refurbishment of the SMK system included upgrading the electrical system for greater power availability, replacement of refractory materials, and a new water-cooled upper lid with five penetrations for the following applications:

- a pipe to connect with the off-gas chiller,

- a water-cooled feeder tube (for feeding sludge into the crucible),

- an opening to install a bubbler tube,

- an opening with a guard rail to provide for operation of the locking device, and

- a viewport to observe the melt.

\section{The EP-5 System}

The EP-5 pilot-scale melter is intended for jouleheated glass production. Figures 7 and 8 provide a schematic representation and general view of the melter system. The design of the EP-5 provides for feeding slurry onto the melt surface, air bubbling, periodic glass pouring, melting temperature monitoring and glass sampling. This configuration allows for extended melter operation.

The melter is a rectangular bath with refractory steel (Kh70/EI-652) main heaters installed along the walls. The area of one electrode inside the bath is $150 \mathrm{~cm}^{2}$. The lower parts of the electrodes are water-cooled. The front wall of the melter bath has a $50 \mathrm{~mm}$ opening for pouring glass, with the lower edge of this opening on the bath bottom level. The pour spout of the bath is combined with the aperture of the locking device. The melter has a melt surface of 338 $\mathrm{cm}^{2}$ and a total volume of approximately $7 \mathrm{~L}$. The working volume is $5 \mathrm{~L}$ and the volume of the poured glass is $2.5 \mathrm{~L}$.

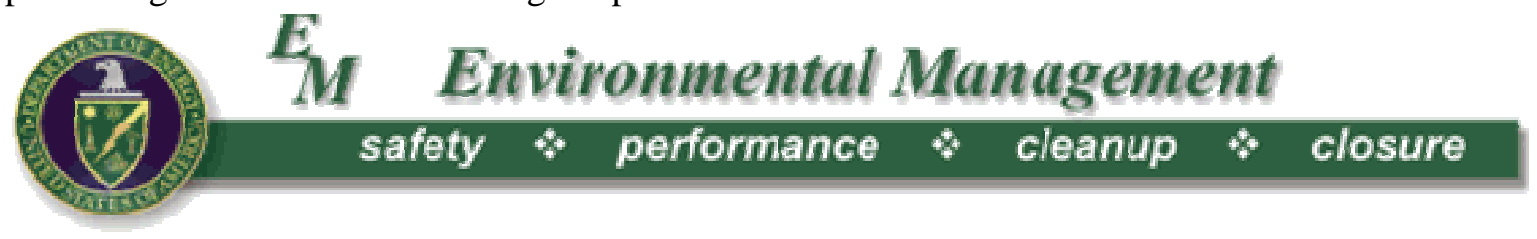




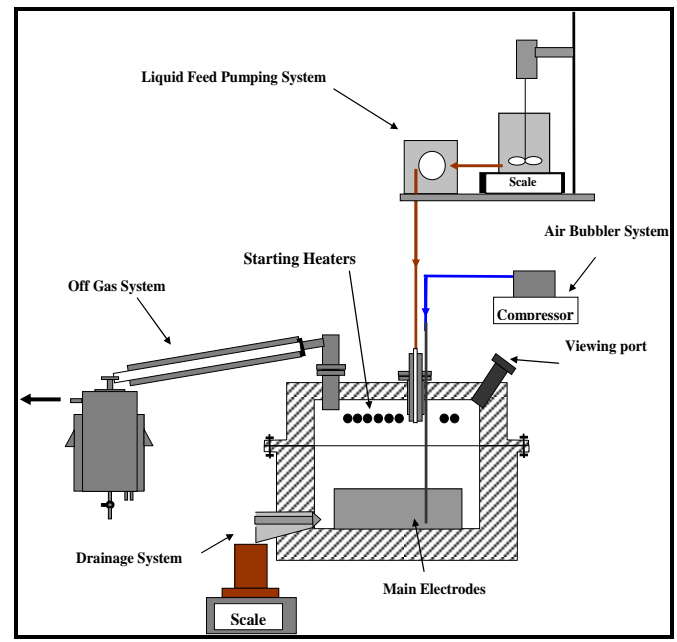

Figure 7. Schematic of the EP-5 System.

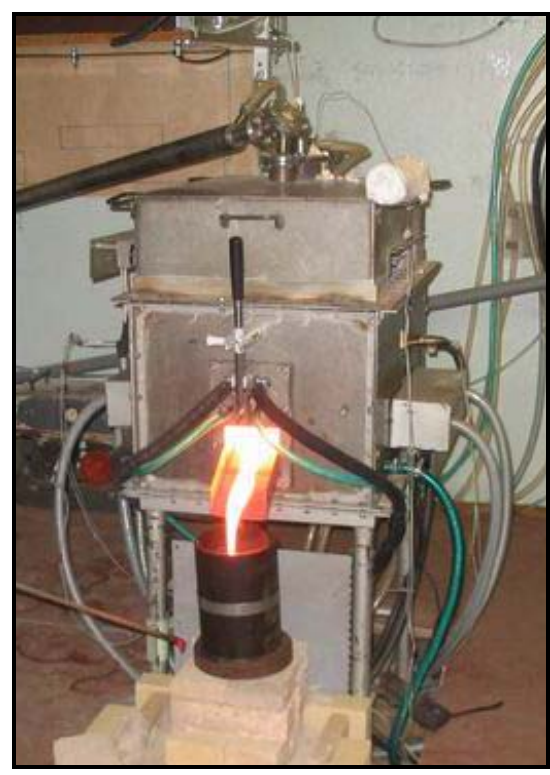

Figure 8. Glass pour from the EP-5 System.

The melter and the pour spout assembly are installed in a steel enclosure with water-cooled walls and bottom and an insulating material between the external walls of the melter bath and the internal walls of the steel enclosure. The upper detachable part of the melter (lid) contains starting silicon carbide heaters required to produce the startup melt. In addition, the lid has openings for installation of the feeder tube, bubbler, integration with the off-gas system and a viewing port for observations of the melt and sampling.

To prepare for testing, KRI performed a number of refurbishment/renovation activities on the EP5 system, specifically:

- fabricated and installed new main electrodes from EI-652 steel,

- installed the melter bath using ceramic refractory (Bacor-33) plates for the walls and bottom and sealed all areas with refractory cement,

- fabricated quartz tubes to protect the starting heaters from splashes and vapors, and

- installed new starting heaters in the quartz tubes and tested startup of the system.

\section{Significant 2007 Accomplishments:}

- The characterization of 70 surrogate glasses was completed.

- The results of the surrogate glass test matrix were used to select compositional regions of interest to Hanford and SRS for melter testing at KRI.

- A system of glass frits was developed for combination with the SRS feeds as part of the KRI melter testing to evaluate melting rates.

- The SMK and EP-5 melters at KRI were refurbished.

- Hanford and SRS sludge simulants were prepared and characterized to support melter testing.

- Testing of the Hanford compositions was completed for both the SMK and EP-5 melters.

- Melter testing with the SRS compositions was initiated.

\section{Planned Activities}

Upon completion of melter testing at KRI, samples of both the poured glass and residual glass from the melters will be evaluated by the International Team for chemical composition,

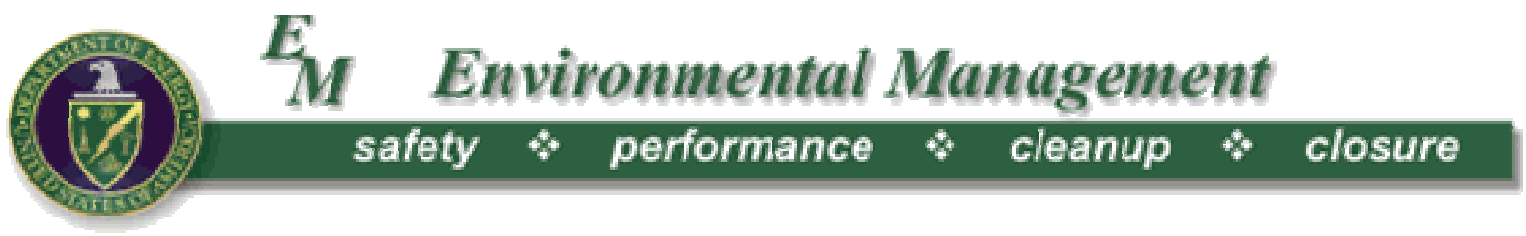


durability and degree/type of crystallization. Melting rate data from KRI for the SRS feeds will be evaluated in combination with data produced from test melters at SRNL to identify frits for potential application to high $\mathrm{Al}_{2} \mathrm{O}_{3}$ concentration feeds at the DWPF. The data from both the surrogate glass test matrix and the melter testing will be used by the International Team to further refine the glass composition/properties models that are used to support high-level waste vitrification in the DOE complex. Formulation and processing data from the Hanford High Al waste glass will be used to expand the composition region for Hanford waste treatment which will help assess the amount of HLW glass to be produced. 


\section{Long-term Impacts from Radiation/Contamination within the Chernobyl}

\section{Exclusion Zone}

Principal Investigator(s): M. Bondarkov (International Radioecology Laboratory), J.R. Harbour (SRNL)

\section{Research Objectives}

The overall objectives of the project are:

- Assess the long-term impacts to the environment from radiation exposure within the Chernobyl Exclusion Zone (ChEZ).

- Provide information on remediation guidelines and ecological risk assessment within radioactively contaminated territories based on the results of long-term field monitoring, analytical measurements, and numerical modeling of soils and groundwater radioactive contamination.

- Recommend the development and testing of effective cleanup technologies to reduce environmental and health risks.

\section{Research Progress}

There are four subtasks that comprise the overall task:

Task 1 Characterization and Monitoring Methods

The nuclear accident at the Chernobyl nuclear power plant (ChNPP) in 1986 that resulted in destruction of the $4^{\text {th }}$ power unit caused a catastrophic radioactive contamination of the environment. The highest contamination levels were observed in the areas adjacent to the ChNPP including the $30 \mathrm{~km}$ area known as the ChEZ. A report was issued that assessed the
Environmental monitoring methods used during and after decommissioning of the ChNPP.

Comprehensive environmental radiation and contamination monitoring has been and is being performed at ChNPP and the adjacent areas where intense industrial activities are conducted (Figure 9). The environmental radiation monitoring pursues the following goals: (1) obtain information required to assure radiation, environmental and general safety of the personnel and the environment, (2) demonstrate that the actual radiation exposure and the radiation impact associated with the ongoing reactor units decommissioning activates and shelter stabilization activities is within the allowable regulatory limits established by the Ukrainian legislation, (3) perform forecast predictions and risk assessment of the ongoing activities. From this perspective, the ChNPP environmental radiation monitoring meets all safety and quality criteria established in the legislative and regulatory documents.

However, the performed analysis of methods and systems used in the environmental radiation monitoring at ChNPP and the ChEZ has shown that the environmental radiation monitoring does not fully meet the requirements for the environmental remediation management in this area. Specifically, the changes in biological speciation and quantities in the flora and fauna populations in the region are not effectively monitored. A number of parameters associated with chemical and biological degradation linked to the contamination are not sufficiently analyzed. This analysis is important for demonstration and assessment of the natural attenuation. Therefore, the current

\section{E Environmental Management}


environmental radiation monitoring can be improved.

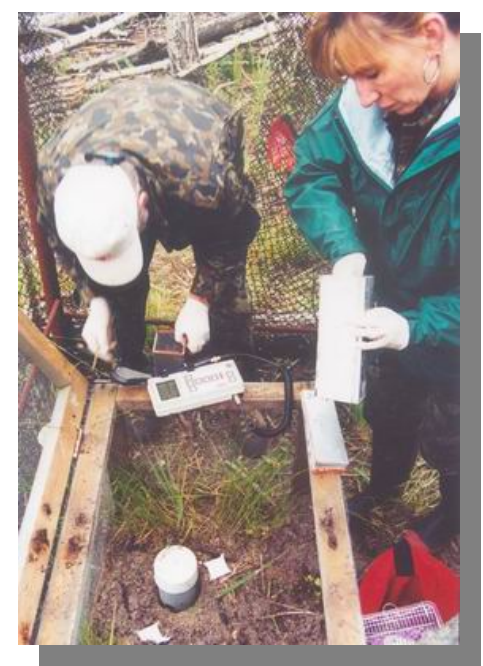

Figure 9. Environmental monitoring in the Chernobyl Exclusion Zone.

Task 2 Understanding of the Processes and Modeling of Fate and Transport of Radionuclides through Environmental Pathways (e.g., soils, groundwater, surface waters, microbiota, plants and animals, etc.)

A summary report has been issued which details the resuspension of radioactive aerosols through natural means such as wind and anthropogenic means such as agriculture and construction. After the initial airborne radioactive release from the ChNPP reactor stopped in 1986, secondary wind transport of radionuclides became the major source of near-surface atmospheric layer contamination. The most significant decrease of airborne radioactive concentrations was observed during the first two years after the accident. Currently, the situation has stabilized. Under natural, weather dependent, conditions the airborne radionuclide concentrations may vary by an order of magnitude during one year. However, during dust storms and wild fires, near-surface airborne radionuclide concentrations may increase by a factor of several hundred times.
Agricultural activities in contaminated areas affect the soil and increase the release of airborne radioactive dust. Therefore, agricultural machine operators and agricultural workers are considered to be one of the highest risk groups with regard to radionuclide inhalation.

Any construction activities in the Chernobyl areas may also cause resuspension of radioactive aerosols. For example, additional studies are required to evaluate wind radioactive transport and personnel dose exposure associated with construction of a new, safe confinement over the shelter structure, especially during the first phase of those construction activities related to laying the foundation. Another example is reclamation of the ChEZ, specifically, the ChNPP cooling pond, since the bottom deposits of that pond contain a large amount of radionuclides.

There have been many studies conducted to analyze the resuspension of radionuclides in aerosols by both international and Ukrainian groups. Currently, there is a reliable near-surface air monitoring system operating in the ChEZ.

A study of soil mycobiota (fungal flora) in the ChEZ also provides insight into the impact of contamination and radiation dose. A report was written that evaluated the effects of microbiological processes on the speciation and transport of radionuclides in soils using existing data plus results from additional studies on strains of micromycetes with positive radiotrophism. It turns out that fungal species can serve as bio-indicators for various degrees of radioactive contamination. The obtained results on the frequency of occurrence of the bioindicating species make it possible to predict the natural remediation of the contaminated areas.

A report was written that reviews literature data on mathematical models for vertical migration of radionuclides in the soil upper layers

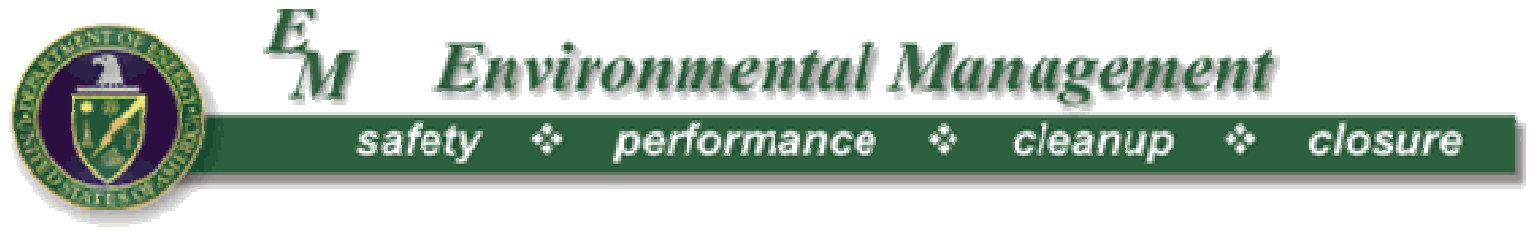


(unsaturated zone). The modeling methods are assessed for a capability of providing a longterm prediction of radionuclide vertical transport in the soil profiles in the ChNPP fallout plume. The majority of approaches evaluate diffusion and convective transport of radionuclides with soil moisture flows. Methods for calculation of radionuclide distributions in soil profiles are described, parameters for radionuclide distribution in various soil layers are identified, exposure dose rates are calculated, and transport parameters calculated using the described models are evaluated. The modified convectivediffusion model for radionuclide transport in soils in the areas of ChNPP fallouts is described in detail for radionuclides in various physical and chemical forms. The model takes into account dynamics of major modes of radionuclide transport in soil.

Task 3 Evaluation of Risk Assessment Methods

The first part of this task consisted of documenting the methods used to assess radiation dose to humans and non-human species. In this report the dose assessments are based on physical measurement and mathematical calculations and do not include biological methods. The calculations for radiation dose include simplifications to deal with the extreme complexity of dose in the actual environment.

Task 4 Evaluation and Demonstration of Cleanup Technologies for RadioactivelyContaminated Sites

The first subtask in Task 4 was to document the analytical techniques used for detecting radionuclides (Sr-90, Pu238, $\mathrm{Pu}-239, \mathrm{Pu}-240$, and $\mathrm{Am}-241$ ) in soils and sediments.

\section{Significant 2007 Accomplishments:}

- Six reports were written summarizing the results described in the previous Section.

\section{Planned Activities}

A series of deliverables has been developed and agreed upon that will summarize the research results from each of the four tasks for 2008. These deliverables include reports on (1) evaluation of potential application of the project results to DOE sites, (2) summary of the evaluation of methods used for radioecological monitoring and data collection at abandoned sites within the ChEZ, (3) summary of the environmental monitoring methods during site restoration activities within the ChEZ, (4) assessment of groundwater contamination caused by the cooling pond at the ChNPP, and (5) evaluation of the results of observations and modeling on natural remediation in meadows and agricultural lands.

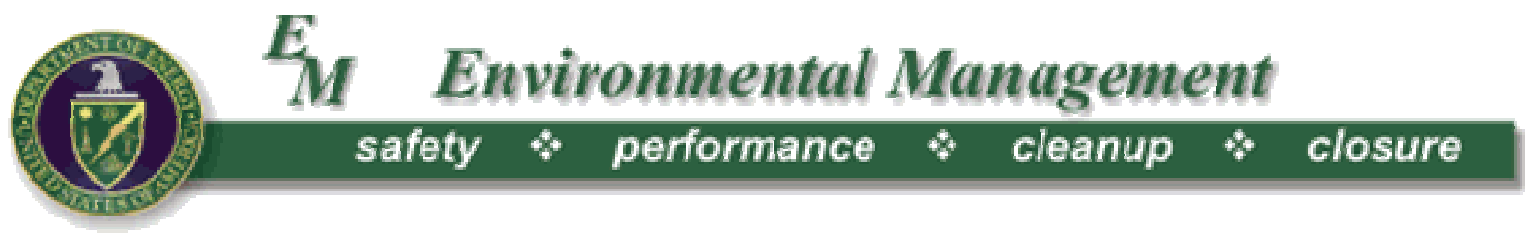




\section{Cold Crucible Induction Melter Demonstration With SRS Slurry Feed Simulant}

Principal Investigator(s): C.W. Kim (NETEC), M.E. Smith (SRNL)

Collaborator(s): T.W. Hwang, J.K. Park, S.J. Maeng, K. Jo (NETEC), A.B. Barnes, J.C. Marra (SRNL)

An effort was initiated in late 2007 to perform testing in the CCIM at the Korea Hydro and Nuclear Power Nuclear Energy and Technology Institute (NETEC) in Daejeon, South Korea. This testing was conducted using a pilot-scale unit that is currently being used as the basis for installation of a radioactive unit in South Korea (Figure 10). This testing will provide relevant CCIM processing data as well as throughput data to support melter scaling for installation in DWPF. This effort is slated for completion in mid-2008.

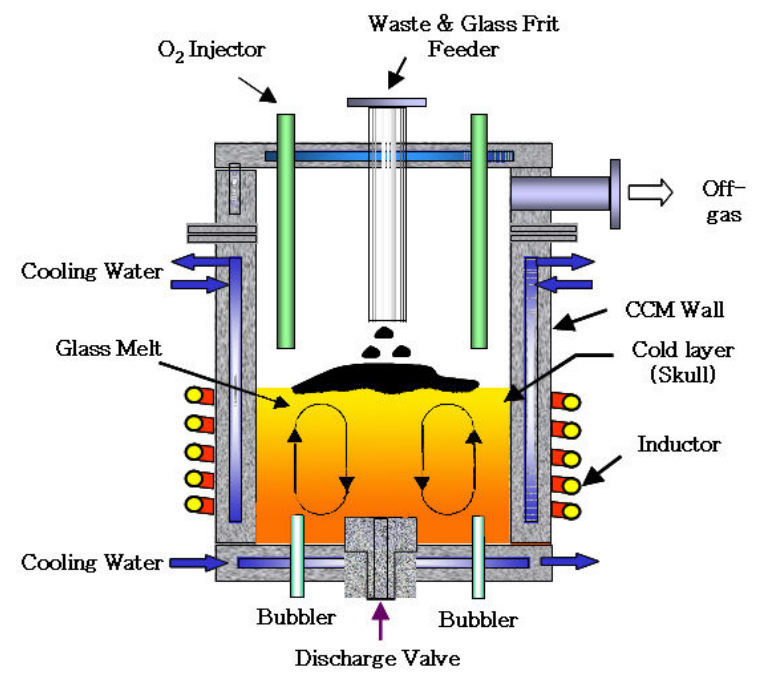

Figure 10. Schematic of the NETEC CCIM.

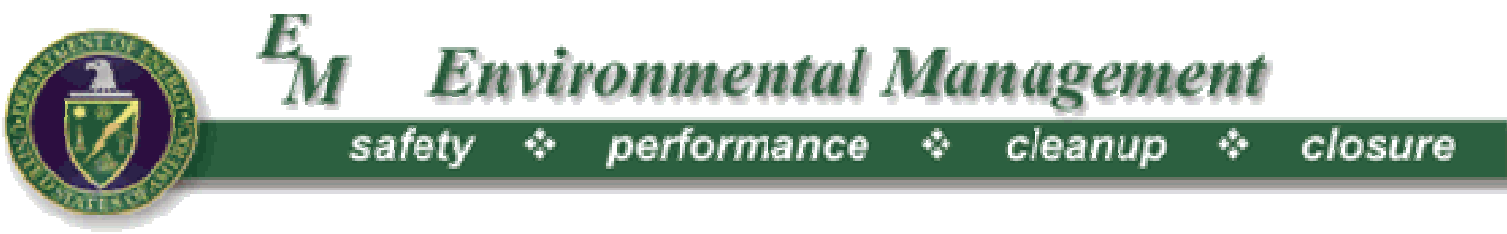




\section{FUTURE INITIATIVES FOR INTERNATIONAL PROGRAM}

The DOE-EM Office of Engineering and Technology is actively engaged in activities to reduce the technical risk in and accelerate DOE's cleanup efforts. To accomplish these goals, technologies are being evaluated and/or developed to provide technical solutions where none exist today, to identify solutions that enhance safety or effectiveness, and to find technologies that reduce overall risk. The effort is focused in three strategic areas: i) waste processing; ii) groundwater and soil remediation; and iii) deactivation and decommissioning (D\&D). Currently, there is a DOE complex-wide effort underway to identify technical needs in each of the strategic areas. To address the technical needs, targeted research and development efforts will be initiated under the auspices of the Office of Engineering and Technology. Additionally, technology reviews and workshops will be conducted to promote sharing of knowledge and lessons learned.

An initiative of the international collaboration program will be to link international experience and expertise to these technical needs to foster further collaboration with international partners. The current international partnerships will be leveraged for this effort. Additionally, other international experts will be identified. For example, discussions are underway to expand CCIM technology sharing with NETEC in South Korea. As another example, dialog has been initiated with representatives from the Nuclear Decommissioning Authority (NDA) in the United Kingdom. A Statement of Intent was recently signed between DOE-EM and the NDA to work cooperatively on areas of mutual interest. Under this umbrella, discussions were held with NDA representatives to identify potential areas for collaboration. Information and technical exchanges were identified as near-term actions to help meet the objectives of the Statement of Intent. Collaborative research opportunities will be identified in the future when the DOE-EM Engineering and Technology road map and multi-year program planning efforts are finalized. Comparisons of the DOE-EM technology planning documents and the NDA technology development business plan will be used to identify target areas for future collaborative work.

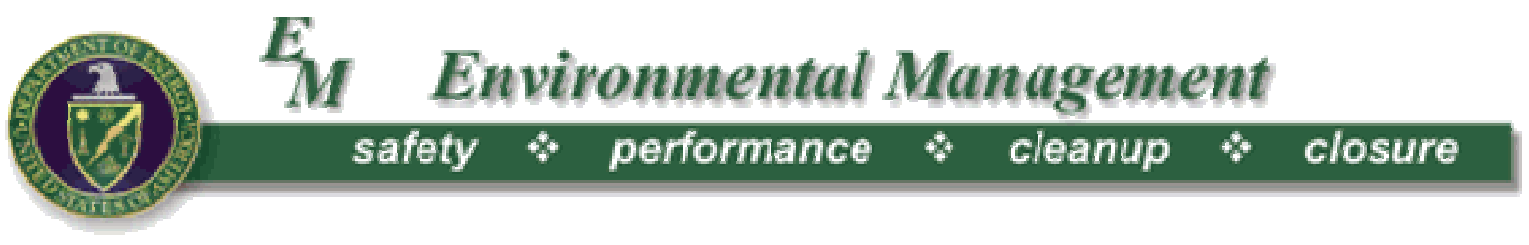




\section{PAPERS/PRESENTATIONS RESULTING FROM PROJECTS}

I.R. Triay and K.D. Gerdes, “Solving Cleanup Challenges Through Risk Reduction,” 2007 International Conference on Environmental Remediation and Radioactive Waste Management (ICEM), Bruges Belgium, September 2007.

S.L. Krahn, "EM Engineering and Technology: Reducing Technical Risks and Uncertainties in EM Projects,” Proceedings of International Symposium on Radiation Safety Management, Daejeon, South Korea, November 2007.

J.E. Marra, “Towards a Global Nuclear Renaissance: A New Paradigm for Waste Management,” Proceedings of International Symposium on Radiation Safety Management, Daejeon, South Korea, November 2007.

S.V. Stefanovsky, B.S. Nikonov, and J.C. Marra, "Characterization of the Glass-Ceramic Material Prepared Upon Vitrification of an Iron-containing Surrogate of High-level Wastes in a Cold Crucible,” Glass Physics and Chemistry (Russian), Vol. 33, number 6, December 2007.

J.C. Marra, D.K. Peeler, T.B. Edwards, K.M. Fox, J.D. Vienna, A. Fluegel, S.V. Stefanovsky, A.S. Aloy, "Glass Formulation Development to Support Melter Testing to Demonstrate Enhanced High Level Waste Throughput,” MRS 2007 Scientific Basis for Nuclear Waste Management XXXI, Sheffield, UK., in press.

S.V. Stefanovsky, A.G. Ptashkin, O.A. Knyazev, M.S. Zen’kovskaya, J.C. Marra, “Cold Crucible Vitrification of Uranium-Bearing High Level Waste Surrogate,” MRS 2007 Scientific Basis for Nuclear Waste Management XXXI, Sheffield, UK., in press.

A.P. Kobelev, S.V. Stefanovsky, V.V. Lebedev, M.A. Polkanov, A.G. Ptashkin, J.C. Marra, "Vitrification of Simulated Iron-Aluminum High-Level Radwaste: Experimental Results,” Environmental Safety, 2008, N1. P. 44-46.

S.V. Stefanovsky, A.P. Kobelev, V.V. Lebedev, M.A. Polkanov, A.G. Ptashkin, O.A. Knyazev, J.C. Marra, "Vitrification of Savannah River Site SB4 Waste Surrogate in the Radon Bench-Scale Cold Crucible Unit,” Waste Management 2008 Conference, Phoenix, AZ, in press.

K.D. Gerdes, J.C. Marra, D.K. Peeler, J.R. Harbour, K.M. Fox, J.D. Vienna, A.S. Aloy, S. V. Stefanovsky, and M.D. Bondarkov, "Current Progress and Future Plans for the DOE Office of Environmental Management International Program,” Waste Management 2008 Conference, Phoenix, AZ, in press.

D.S. Kim, J. Vienna, D. Peeler, K. Fox, A. Aloy, A. Trofimenko, K. Gerdes, "Improved Alumina Loading in High-Level Waste Glasses,” Waste Management 2008 Conference, Phoenix, AZ, in press.

S.V. Stefanovsky, A.P. Kobelev, V.V. Lebedev, M.A. Polkanov, A.G. Ptashkin, O.A. Knyazev, J.C. Marra, "Cold Crucible Vitrification of Savannah River Site SB4 Waste Surrogate: Process Variables and Product Characterization,” The American Ceramic Society's 2008 Glass and Optical Materials Division Meeting, Tucson, AZ, presentation.

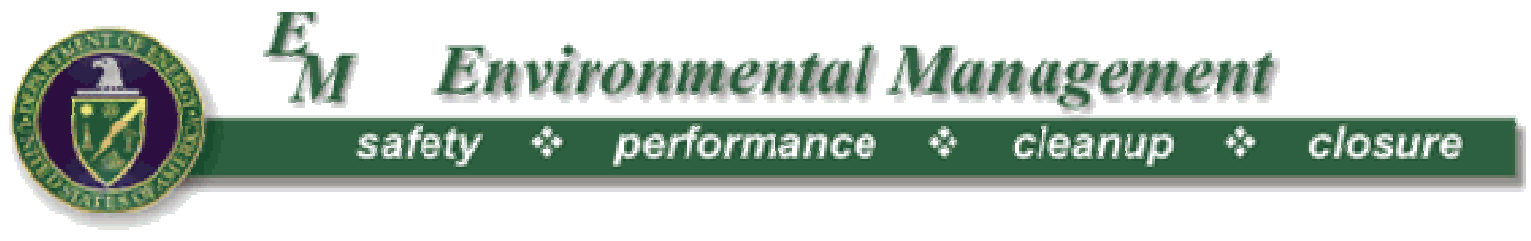


A.P. Kobelev, S.V. Stefanovsky, V.V. Lebedev, M.A. Polkanov, O.A. Knyazev, A.G. Ptashkin, J.C. Marra, "Vitrification of Waste Surrogate of Savannah River Plant (USA) with High Iron and Aluminum Content at the Bench- and Industrial-Scale Plants with Cold Crucible,” Atomic Energy (Russian), in press.

S.V. Stefanovsky, A.A. Shiryaev, J.V. Zubavitchus, A.A. Veligjanin, J.C. Marra. "Valence State and Speciation of Uranium Ions in Borosilicate Glasses with High Iron and Aluminum Content,” Glass Physics and Chemistry (Russian), in press.

S.V. Stefanovsky, "Experience of Savannah River Nuclear Site’s Radioactive Waste Liquid Vitrification using Cold-crucible Melters,” AtomEco-2007, Moscow, Russia, December 2007.

\section{RECOGNITIONS RESULTING FROM DOE-EM INTERNATIONAL PROGRAM}

Chairmanship for International Commission on Glass - Technical Committee on Nuclear and Hazardous Waste Vitrification.

Chairmanship for American Ceramic Society - Nuclear and Environmental Technology Division

Organizing Committee for MRS 2007 Scientific Basis for Nuclear Waste Management XXXI, Sheffield, UK.

Organizing Committee for 2009 International Symposium on Radiation Safety Management

Organizing Committee for 2009 International Conference on Environmental Remediation and Radioactive Waste Management (ICEM), Liverpool, U.K.

Organizing Committee for MRS 2009 Scientific Basis for Nuclear Waste Management XXXII, St. Petersburg, Russia

Organizing Committee for 2009 International Commission on Glass Conference, Vancouver, Canada.

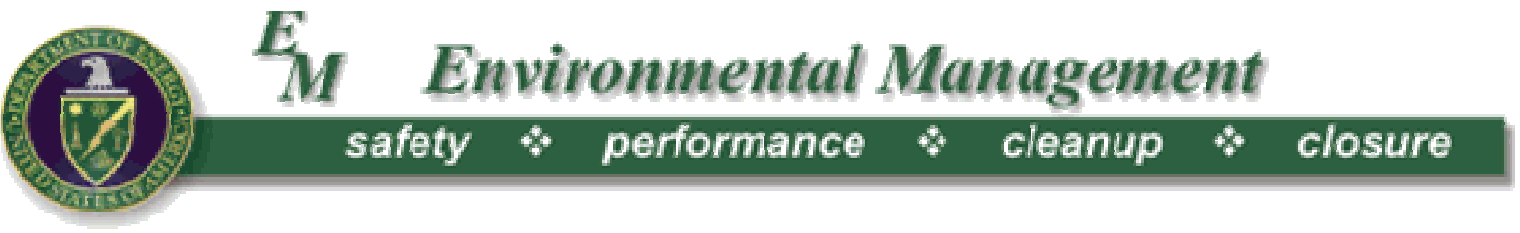




\title{
APPENDIX A - ABSTRACTS FOR 2007 PAPERS
}

\section{Towards a Global Nuclear Renaissance: A New Paradigm for Waste}

\section{Management}

Proceedings of International Symposium on Radiation Safety Management, Daejeon, South Korea, November 2007.

\section{J. E. Marra}

Energy availability is the engine that drives economic growth. With fuel oil and natural gas prices near record highs, and worldwide energy demands increasing at an alarming rate, there is growing international interest in revitalization of nuclear power. Additionally, growing concerns about environmental impacts from burning of fossil fuels has turned even anti-nuclear groups into proponents for increased use of nuclear power. In order to achieve the vision of a revitalized nuclear industry, issue associated with waste generation must be addressed, and indeed, must be a primary consideration in any future planning scenario. As part of the United States Department of Energy Global Nuclear Energy Partnership (GNEP), an Integrated Waste Management Strategy is being developed. This strategy considers waste disposition as a primary consideration for any deployment scenario.

\section{Characterization of the Glass-Ceramic Material Prepared Upon Vitrification of an Iron-containing Surrogate of High-level Wastes in a Cold Crucible}

Glass Physics and Chemistry (Russian), Vol. 33, number 6, December 2007.

S. V. Stefanovsky, B. S. Nikonov, and J. C. Marra

\begin{abstract}
Vitreous materials are prepared by cold crucible induction melting of a surrogate of high-level wastes (from the Savannah River Site, United States) and a borosilicate glass frit taken in mass ratios from 45:55 to $60: 40$. According to the X-ray diffraction and electron microscopic data, the vitreous materials thus produced consist of a glass matrix and a magnetite-type spinel enriched in transition elements. The degree of crystallinity of the materials increases with an increase in the waste oxide content from 6 to 18-20 vol $\%$. The vitreous materials are characterized by a high chemical durability, which decreases only at high contents of the waste oxides (55 wt \% and higher) due to the formation of an additional nepheline phase.
\end{abstract}

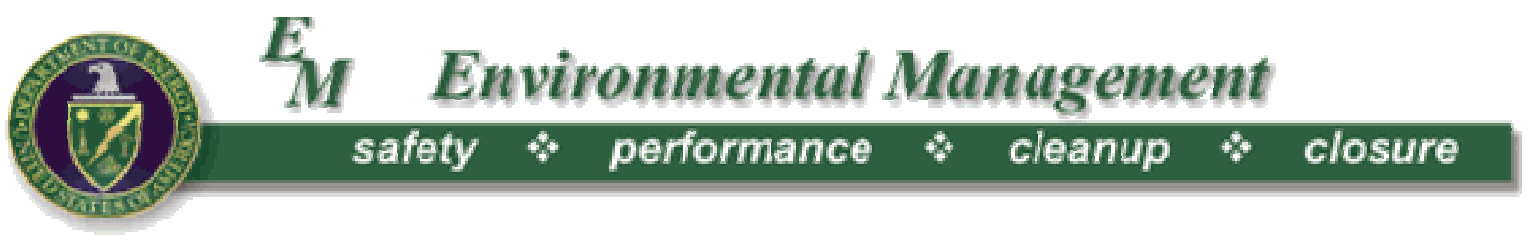




\title{
Glass Formulation Development in Support of Melter Testing to Demonstrate Enhanced High Level Waste Throughput
}

MRS 2007 Scientific Basis for Nuclear Waste Management XXXI, Sheffield, UK., in press.

James C. Marra, Kevin M. Fox, David K. Peeler, Thomas B. Edwards, Amanda L. Youchak, James H. Gillam, Jr., John D. Vienna ${ }^{1}$, Sergey V. Stefanovsky², and Albert S. Aloy ${ }^{3}$

Savannah River National Laboratory, Aiken, SC, U.S.A., ${ }^{1}$ Pacific Northwest National Laboratory, Richland, WA, U.S.A.; ${ }^{2}$ SIA Radon Institute, Moscow, Russia; ${ }^{3}$ V. G. Khlopin Radium Institute, St. Petersburg, Russia

\begin{abstract}
The U.S. Department of Energy (DOE) is currently processing high-level waste (HLW) through a Jouleheated melter (JHM) at the Savannah River Site (SRS) and plans to vitrify HLW and Low activity waste (LAW) at the Hanford Site. Over the past few years at the Defense Waste Processing Facility (DWPF), work has concentrated on increasing waste throughput. These efforts are continuing with an emphasis on high alumina concentration feeds. High alumina feeds have presented specific challenges for the JHM technology regarding the ability to increase waste loading yet still maintain product quality and adequate throughput. Alternatively, vitrification technology innovations are also being investigated as a means to increase waste throughput. The Cold Crucible Induction Melter (CCIM) technology affords the opportunity for higher vitrification process temperatures as compared to the current reference JHM technology. Higher process temperatures may allow for higher waste loading and higher melt rate.

Glass formulation testing to support melter demonstration testing was recently completed. This testing was specifically aimed at high alumina concentration wastes. Glass composition/property models developed for DWPF were utilized as a guide for formulation development. Both CCIM and JHM testing will be conducted so glass formulation testing was targeted at both technologies with a goal to significantly increase waste loading and maintain melt rate without compromising product quality.
\end{abstract}

\section{Cold Crucible Vitrification of Uranium-Bearing High Level Waste Surrogate}

MRS 2007 Scientific Basis for Nuclear Waste Management XXXI, Sheffield, UK., in press.

S.V. Stefanovsky, A.G. Ptashkin, O.A. Knyazev, M.S. Zen’kovskaya and J.C. Marra

\section{ABSTRACT}

Three tests on vitrification of U-bearing SB2 and SB4 waste surrogates (40-50 wt.\% waste loading) in a lab-scale (56 mm inner diameter) copper cold crucible with melt surface area of $24.6 \mathrm{~cm}^{2}$ energized from a $5.28 \mathrm{MHz} / 10 \mathrm{~kW}$ generator were conducted. Glass productivity and specific melt productivity achieved under steady-state conditions were $0.64 \mathrm{~kg} / \mathrm{h}$ and $256 \mathrm{~kg} /\left(\mathrm{m}^{2} \times \mathrm{h}\right)\left[6150 \mathrm{~kg} /\left(\mathrm{m}^{2} \times\right.\right.$ day $\left.)\right]$, respectively. Similar to previously prepared U-free products, the U-bearing vitrified SB2 (high-ferrous) waste product

\section{E Environmental Management}


was composed of U-enriched glassy matrix and high-ferrous spinel structure phase. As expected, the vitreous phase in the vitrified SB2 waste surrogate was enriched with $\mathrm{Na}, \mathrm{Al}, \mathrm{Si}, \mathrm{P}, \mathrm{S}, \mathrm{Ca}, \mathrm{Sr}, \mathrm{Pb}, \mathrm{U}$ oxides and $\mathrm{Cl}$, whereas spinel preferentially accumulated transition metals (iron group elements: $\mathrm{Mn}, \mathrm{Fe}$, $\mathrm{Ni}$ ) as well as $\mathrm{Cu}$ and $\mathrm{Zn}$ oxides. Iron oxide content in the spinel phase was $\sim 67-71 \mathrm{wt} . \%$. This result was consistent with XRD data and implies that this spinel was close to magnetite with respect to chemical composition and structure. This was consistent with our previous data on characterization of glass crystalline materials containing both U-bearing and U-free SB2 waste surrogate produced in resistive furnace and cold crucibles. The vitrified SB4 (high-alumina) waste products were predominantly amorphous at waste loading of up to $50 \mathrm{wt}$ \%. Traces of quartz occurred in the "skull" zone. In all the products, uranium was found to be uniformly distributed within the vitreous phase. Leach rates of $\mathrm{Na}, \mathrm{Si}$, Fe, and U from the vitrified SB2 waste surrogate (50 wt.\% waste loading) determined by a SPFT

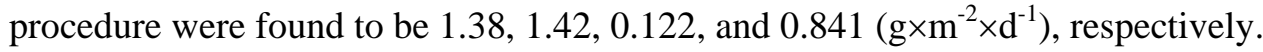

\section{Vitrification of Simulated Iron-Aluminum High-Level Radwaste: Experimental Results}

Environmental Safety (Russian), 2008, N1. P. 44-46.

A.P. Kobelev, S.V. Stefanovsky, V.V. Lebedev, M.A. Polkanov, A.G. Ptashkin and J.C. Marra

\section{ABSTRACT}

Vitrification is an internationally acknowledged method of high-level waste management. This method helps to considerably reduce the amount of radwaste and obtain a waste product that is resistant to environmental factors and suitable for long-term storage.

\section{Vitrification of Savannah River Site SB4 Waste Surrogate in the Radon Bench- Scale Cold Crucible Unit}

Waste Management 2008 Conference, Phoenix, AZ, in press.

S.V. Stefanovsky, A.P. Kobelev, V.V. Lebedev, M.A. Polkanov, A.G. Ptashkin, O.A. Knyazev, and J.C. Marra

\section{ABSTRACT}

The bench scale cold crucible tests on vitrification of Savannah River Site SB4 waste surrogate were performed using a $236 \mathrm{~mm}$ inner diameter stainless steel cold crucible energized from a $1.76 \mathrm{MHz} / 60 \mathrm{~kW}$ high frequency generator. Waste loading in glass ranged between 40 and $60 \mathrm{wt} \%$. The waste/glass formers mixtures were fed as slurry with a water content of $~ 31-32 \mathrm{wt} . \%$ (40 wt.\% waste loading) and $42-$ $43 \mathrm{wt.} \%$ (60 wt.\% waste loading). Major process variables were as follows: average slurry feed rate and melt pour rate (productivity): 8.5 and $3.0 \mathrm{~kg} / \mathrm{hr}$, respectively, specific melt productivity: 1650 $\mathrm{kg} /\left(\mathrm{m}^{2} \times\right.$ day $)$, and melting ratio: $14.7 \mathrm{~kW} \times \mathrm{hr} / \mathrm{kg}$. The vitrified product is composed of major vitreous and

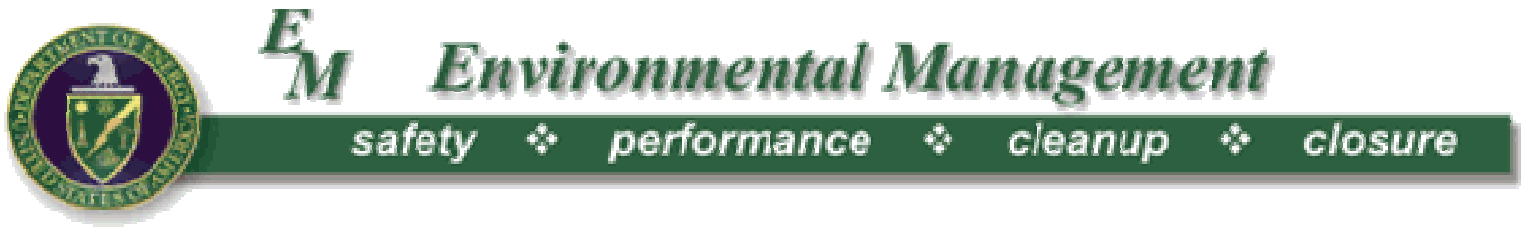


minor crystalline spinel type phases. The degree of crystallinity increases with the increase of waste loading and reaches $\sim 10$ vol.\% in the product at $60 \mathrm{wt} . \%$ waste loading.

\section{Current Progress and Future Plans for the DOE Office of Environmental Management International Program}

Waste Management 2008 Conference, Phoenix, AZ, in press.

K.D. Gerdes, J.C. Marra, D.K. Peeler, J.R. Harbour, K.M. Fox, J.D. Vienna, A.S. Aloy, S. V. Stefanovsky, and M.D. Bondarkov

\section{ABSTRACT}

The U.S. Department of Energy's (DOE) Office of Environmental Management (EM) has collaborated with various international institutes for many years on radioactive waste management challenges of mutual concern. Currently, DOE-EM is performing collaborative work with researchers at the Khlopin Radium Institute and the SIA Radon Institute in Russia and the Ukraine's International Radioecology Laboratory to explore issues related to high-level waste and to investigate experience and technologies that could support DOE-EM site cleanup needs. Specific initiatives include:

- Application of the Cold Crucible Induction Heated Melter to DOE Wastes - SIA Radon and Savannah River National Laboratory;

- Improved Solubility and Retention of Troublesome Components in SRS and Hanford Waste Glasses - Khlopin Radium Institute, Pacific Northwest National Laboratory and Savannah River National Laboratory

- Long-term Impacts from Radiation/Contamination within the Chernobyl Exclusion Zone, International Radioecology Laboratory and Savannah River National Laboratory.

This paper provides an overview of the status of the current International Program task activities. The paper will also provide insight into the future direction for the program. Specific ties to the current DOEEM technology development multi-year planning effort will be highlighted as well as opportunities for future international collaborations.

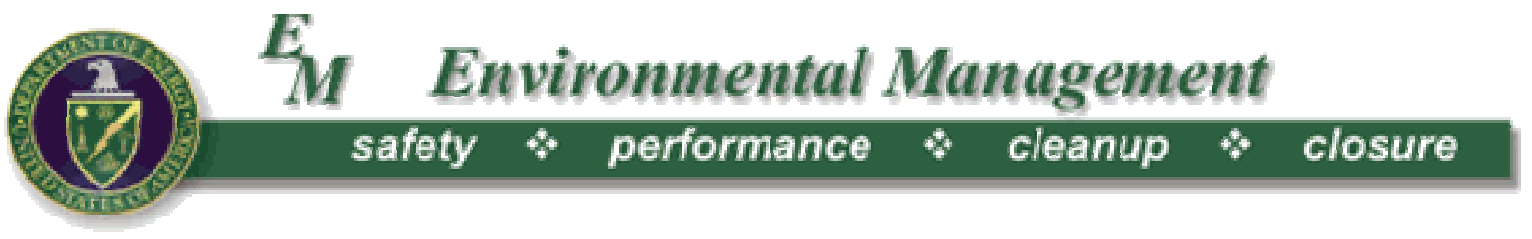




\title{
Improved Alumina Loading in High-Level Waste Glasses
}

Waste Management 2008 Conference, Phoenix, AZ, in press.

D.S. Kim, J. Vienna, D. Peeler, K. Fox, A. Aloy, A. Trofimenko and K. Gerdes

\begin{abstract}
Recent tank retrieval, blending, and treatment strategies at both the Savannah River Site (SRS) and Hanford have identified increased amounts of high- $\mathrm{Al}_{2} \mathrm{O}_{3}$ waste streams that are scheduled to be processed through their respective high-level waste (HLW) vitrification facilities. It is well known that the addition of small amounts of $\mathrm{Al}_{2} \mathrm{O}_{3}$ to borosilicate glasses generally enhances the durability of the waste glasses. However, at higher $\mathrm{Al}_{2} \mathrm{O}_{3}$ concentrations nepheline $\left(\mathrm{NaAlSiO}_{4}\right)$ formation can result in a severe deterioration of the chemical durability of the slowly cooled glass near the center of the canister. Additionally, higher concentrations of $\mathrm{Al}_{2} \mathrm{O}_{3}$ generally increase the liquidus temperature of the melt and decrease the processing rate. Pacific Northwest National Laboratory (PNNL), Savannah River National Laboratory (SRNL), and Khlopin Radium Institute (KRI) are jointly performing laboratory and scaledmelter tests, through US Department of Energy, EM-21 Office of Waste Processing program, to develop glass formulations with increased $\mathrm{Al}_{2} \mathrm{O}_{3}$ concentrations. These glasses are formulated for specific DOE waste compositions at Hanford and Savannah River Site. The objectives are to avoid nepheline formation while maintaining or meeting waste loading and/or waste throughput expectations as well as satisfying critical process and product performance related constraints such as viscosity, liquidus temperature, and glass durability. This paper summarizes the results of recent tests of simulated Hanford HLW glasses containing up to $26 \mathrm{wt} \% \mathrm{Al}_{2} \mathrm{O}_{3}$ in glass.
\end{abstract}

\section{Cold Crucible Vitrification of Savannah River Site SB4 Waste Surrogate:}

\section{Process Variables and Product Characterization}

The American Ceramic Society's 2008 Glass and Optical Materials Division Meeting, Tucson, AZ

S.V. Stefanovsky, A.P. Kobelev, V.V. Lebedev, M.A. Polkanov, A.G. Ptashkin, O.A. Knyazev, and J.C. Marra

\section{ABSTRACT}

Savannah River Site (SRS) SB4 high level waste (HLW) surrogate were vitrified with a commercially procured frit ( $8 \mathrm{wt} \% \mathrm{Li}_{2} \mathrm{O}, 16 \mathrm{wt} \% \mathrm{~B}_{2} \mathrm{O}_{3}, 76 \mathrm{wt} \% \mathrm{SiO}_{2}$ ) in lab-, bench-, and large-scale cold crucible melters at the Radon facility. Maximum specific glass productivity achieved was $\sim 2450 \mathrm{~kg} /\left(\mathrm{m}^{2} \times \mathrm{d}\right)$. The vitrified product with $\sim 50 \mathrm{wt} \%$ waste loading was primarily vitreous with a minor ( $\leq 12 \mathrm{vol} . \%)$ crystalline spinel-type phase. All the uranium introduced was found homogeneously distributed in the vitreous phase as major $\mathrm{U}(\mathrm{VI})$ and minor $\mathrm{U}(\mathrm{V})$ having an axially distorted tetrahedral environment. The glassy products exhibited high chemical durability readily meeting current acceptance requirements.

\section{E Environmental Management}




\title{
Vitrification of Waste Surrogate of Savannah River Plant (USA) with High Iron and Aluminum Content at the Bench- and Industrial-Scale Plants with Cold Crucible
}

Atomic Energy (Russian), in press.

A.P. Kobelev, S.V. Stefanovsky, V.V. Lebedev, M.A. Polkanov, O.A. Knyazev, A.G. Ptashkin and J.C. Marra

\begin{abstract}
Cold crucible vitrification tests of Savannah River Site (USA) high level waste surrogate containing up to 29 wt. $\% \mathrm{Fe}_{2} \mathrm{O}_{3}$ and up to 26 wt. $\% \mathrm{Al}_{2} \mathrm{O}_{3}$ at up to 60 wt.\% waste loading were conducted. Specific glass productivity and melting ratio were up to 1700 and $2450 \mathrm{~kg} /\left(\mathrm{m}^{2} \cdot \mathrm{d}\right)$ and $14-16$ and $9-10 \mathrm{~kW} \cdot \mathrm{hr} / \mathrm{kg}$ at the bench- and full-scale units, respectively. No appreciable corrosion of the crucibles during test time was found and the crucibles are suitable for further operation. The product was composed of borosilicate matrix containing up to 10 vol.\% spinel crystalline phase. The inductive cold crucible melting is the most efficient in the large-diameter cold crucibles due to higher specific productivity and lower melting ratio (specific heat expenses) for high level waste vitrification.
\end{abstract}

\section{Valence State and Speciation of Uranium Ions in Borosilicate Glasses with High Iron and Aluminum Content}

Glass Physics and Chemistry (Russian), in press.

S.V. Stefanovsky, A.A. Shiryaev, J.V. Zubavitchus, A.A. Veligjanin and J.C. Marra

\begin{abstract}
Valence state and local environment of uranium ions in borosilicate glasses for immobilization of high level waste with high iron and aluminum contents were studied using X-ray absorption (XANES and EXAFS) techniques. It has been shown that in the glasses containing mainly iron at least $80 \%$ of total uranium exists in a hexavalent form as uranyl ions. In the high-alumina glasses the uranium was found to be in hexa- and pentavalent states; at that, the fraction of the latter increases with the increase of uranium concentration and its local environment is close to a configuration of the axially-distorted tetrahedron.
\end{abstract}

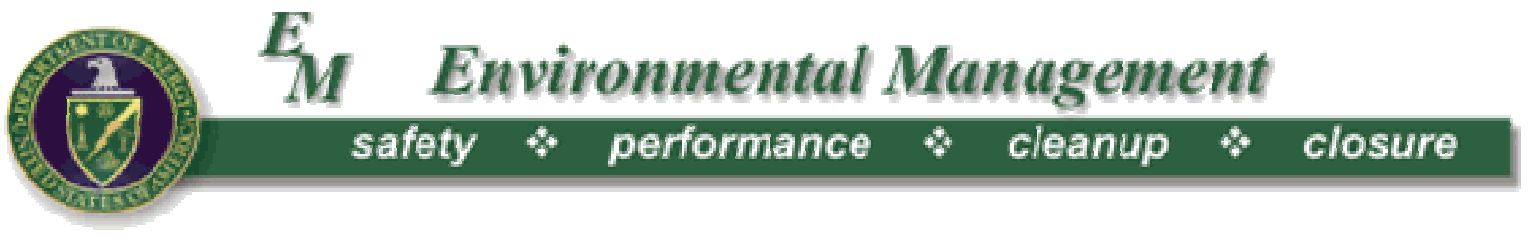

